Науковий вісник Дьвівського націонадьного університету ветеринарної медицини та біотехнологій імені С.3. Гжицького

\author{
Scientific Messenger of Lviv National University \\ of Veterinary Medicine and Biotechnologies
}

\title{
Reproductive qualities, exterior features and the quality of the pery of obroshinsky gray geese at their dissolution «inside»
}

\author{
L. Sloboda ${ }^{1}$, O. Sloboda ${ }^{2}$ \\ ${ }^{1}$ Institute of Agriculture of Carpathian Region NAAS, vil. Obroshyno, Pustomyty district, Lviv region, Ukraine \\ ${ }^{2}$ Stepan Gzhytskyi National University of Veterinary Medicine and Biotechnologies Lviv, Ukraine
}

\section{Article info}

Received 07.02.2018

Received in revised form 07.03 .2018

Accepted 12.03.2018

Institute of agriculture of Carpathian region of Ukraine Hrushevskoho Str., 5 ,

vil. Obroshyno, Pustomyty district,

Lviv region, 81115 , Ukraine.

E-mail: dribne.obroshyno@gmail.com

Stepan Gzhytskyi National University of Veterinary Medicine and Biotechnologies Lviv,

Pekarska Str., 50, Lviv, 79010,

Ukraine.

Tel.: +38-068-185-63-48

E-mail: oleh.sloboda@gmail.com
Sloboda, L., \& Sloboda, O. (2018). Reproductive qualities, exterior features and the quality of the pery of obroshinsky gray geese at their dissolution "inside». Scientific Messenger of Lviv National University of Veterinary Medicine and Biotechnologies. 20(84), 137-142. doi: 10.15421/nvlvet8425

It was found that the average live weight of geese at the beginning of the oviposition was (OS - 3\% $X$ $O S-3 \%):$ goose $-6.10 \mathrm{~kg}$, goose $-7.30 \mathrm{~kg}$, and $(\mathrm{OS}-5 \% \mathrm{XOS}-5 \mathrm{0}):$ goose $-6,30 \mathrm{~kg}$, goose - 7,37 kg. The average weight of $O S-3$ goose was 39.5 eggs per head, and OS-5 - 41.4 eggs. At the same time, the average weight of eggs in the 1 st group was $154.3 \mathrm{~g}$, and in $\mathrm{II}-158.5 \mathrm{~g}$. The indexes of the forms in the I group consisted of: the length of the egg $-84.4 \mathrm{~mm}$, the width $-55.4 \mathrm{~mm}$, the index of form 65.6 in the second group respectively - $84.3 \mathrm{~mm} ; 56.3 \mathrm{~mm} ; 66.7 \mathrm{~mm}$. The study of the incubation qualities of eggs indicates that the higher fertility was in the goose of the second group and amounted to $85.3 \%$, which is $0.9 \%$ more compared with the I group. It is known that the yield of caterpillars is dependent on fertility and in the 1 st group this indicator was $71.8 \%$, which is $4.3 \%$ less than in the second group (76.1\%). At 9 weeks of age, males of the II group surpassed their peers from the 1st group by chest covering 1.79\%., With a body length of $2.08 \%$, and a kilo length of $7.14 \%$. The same tendency was observed in the shoots of the shin and plyusny, so the males of group II in the first indicator dominated the male and group I by 8,19\%; in the second indicator males of the II group dominated the males of the I group by 6.68\%. At 9 weeks of age, females of group II grouped over their breasts over their peers from the 1st group by $2.40 \%$, with the body length by $3.21 \%$., With the length of the keel - by $2.34 \%$. Length of the leg and shoulders in the females of the 2nd group were the largest and dominated by females and groups I by the first indicator at 5.26\%; in the second indicator, females of the second group dominated the females of the I group by 1.08\%. Males at all investigated periods had higher levels of total protein in serum than females. It was found that males at all investigated periods had higher levels of total protein in serum than females. Performance indicators of Ohorin gray geese (Group I) consisted of: carcass weight - $39.5 \mathrm{pc}$. on the head; the weight of eggs $154.3 \mathrm{~g}$; fertility - 84.4\%; deductibility - 71.8\%; the live weight of geese in the 9-week-old age is $4.52 \mathrm{~kg}$ males and $3.84 \mathrm{~kg}$ females; preservation - 90.7\%. Obroshinsky gray goose (group II) are characterized by the highest indexes in relation to the first group: for fertility by $4.8 \%$, fertility by $0.9 \%$, output by $4.9 \%$, live weight of geese at 9 weeks of age (males) - 1.99\%, (females) by $0.52 \%$, preservation - 2.90\%, egg mass $2.64 \%$. The highest feather-down raw material was obtained at the age of 18 in geese I group. The basic indices of blood of the examined geese were within the acceptable limits of the norm.

Key words: obroshyno gray goose, live weight, article sizes, reproductive qualities, carrier, incubation qualities, exterior, quality of feathers.

\section{Репродуктівні якості, особливості екстер'сру і якість пір'я оброшинських сірих гусей при їх розведенні «в собі»}

\author{
Л.Я. Слобода ${ }^{1}$, О.М. Слобода ${ }^{2}$ \\ ${ }^{1}$ Інститут сільського господарства Карпатського регіону НААНУ, с. Оброшино, Пустомитівського р-ну \\ Львівськоӥ обл., Украӥна \\ ${ }^{2}$ Львівський національний університет ветеринарної медицини та біотехнологій імені С.3. Гэницкого, \\ м. Львів, Украӥна
}


Встановлено, що середня жива маса гусей на початок яйцекладки становила (ОС - 3 О Х ОС - 3ठ): гуски - 6,10 кг, гусаки 7,30 кг, а (OC-5ㅇ Х ОС-5今): гуски - 6,30 кг, гусаки - 7,37 кг. Середня несучість ОС-3 гусок становила 39,5 штук яєиь на голову, а ОС-5 - 41,4 штук яєиь. При иьому середня маса яйия у I групі становила 154,3 г, а у II - 158,5 г. Індекси форми у I групі становили: довжина яйия - 84,4 мм, ширина - 55,4 мм, індекс форми - 65,6, у II групі відповідно - 84,3 мм; 56,3 мм; 66,7 мм. Вивчення інкубаційних якостей яєць свідчить, щчо вища запліднюваність була у гусок II групи і становила 85,3\%, щзо на 0,9\% більще порівняно з І групою. Відомо, щзо вивід гусенят залежить від запліднюваності і у I групі ияей показник становив 71,8\%, ияо на 4,3\% менше ніж у II групі (76,1\%). У 9-тижневому віці самиі II групи переважали своӥх ровесників з I групи за обхватом грудей на 1,79\%, за довжиною тулуба на 2,08\%, а за довжиною кіля - на 7,14\%. Така ж тенденція зберігалася і у промірах гомілки та плюсни, так самиі II групи за першим показником переважали самиів I групи на 8,19\%; за другим показником самці II групи переважали самців I групи на 6,68\%. У 9-тижневому віці самки II групи за обхватом грудей переважали своїх ровесниць з I групи на 2,40\%, за довжиною тулуба на 3,21\%, за довжиною кіля - на 2,34\%. Проміри гомілки та плюсни у самок II групи були найбільші й переважали самок I групи за першим показником на 5,26\%, за другим показником самки II групи переважали самок I групи на 1,08\%. Самці в усіх досліджуваних періодах мали вищі показники вмісту загального білка в сироватці крові, ніж самки. Встановлено, щзо самці в усіх досліджуваних періодах мали вищі показники вмісту загального білка в сироватці крові порівняно з самками. Показники продуктивності оброшинських сірих гусей (І група) становили: несучість - 39,5 шт. на голову; маса яйця - 154,3 г; запліднюваність 84,4\%; виводимість - 71,8\%; жива маса гусей в 9-тижневому віці: самџі - 4,52 кг, самки - 3,84 к2; збереженість - 90,7\%. Оброиинські сірі гуси (II група) характеризуються стосовно до I групи відповідно вищими показниками: за несучістю на 4,8\%, запліднюваністю - 0,9\%, виводимістю - 4,9\%, живою масою гусей в 9-тижневому віці (самиі) - 1,99\%, (самки) - 0,52\%, збереженістю 2,90\%, масою яйия - 2,64\%. Вищу перо-пухову сировину було одержано у 18-тижневому віці в гусей I групи. Основні показники крові піддослідних гусей перебували в допустимих межах норми.

Ключові слова: оброшинські сірі гуси, жива маса, проміри статей, репродуктивні якості, несучість, інкубаційні якості, екстер'єр, якість пір'я.

\section{Вступ}

Наша робота базується на попередніх дослідженнях, які переконливо довели, що в умовах західного регіону гуси оброшинської селекції добре пристосовані до місцевих умов годівлі та утримання і 3 ними потрібно проводити селекційну роботу в напрямку збереження та розширення популяції (Petriv et al., 2016; Petriv et al., 2017).

Актуальність теми В другій половині минулого століття в Інституті сільського господарства Карпатського регіону НААНУ вченими під керівництвом Є.М. Охріменко була створена породна група оброшинських сірих та білих гусей, яка виведена методом схрещування місцевих білих, китайських сірих і великих сірих гусей та поєднує в собі ознаки всіх цих порід: значну кількість пуху і пір'я білих гусей з життєздатністю, невибагливістю до корму, ніжністю м’яса і високою несучістю китайських, а також з великою живою масою, скороспілістю і добрими м'ясними якостями великих сірих гусей, які характеризуються високими продуктивними якостями і доброю пристосованістю до природно-кліматичних умов зони розведення (Rojter et al., 2007; Sedilo et al., 2014; Petriv et al., 2015).

Важливими умовами розвитку м'ясного птахівництва сьогодні слід вважати збереження та удосконалення існуючих ліній, кросів, порід та популяцій, комплексну оцінку родинних форм за відтворними якостями, розробку моделей основних селекційних ознак птиці, застосування оцінки за їх елементами, вивчення реакції генотип-середовище, збереження та раціональне використання генофонду птиці, а також розробку і обгрунтування селекційних технологій 3 використанням методів неспецифічної дії (Hunchak et al., 2015; Medvid et al., 2017).

В даний час $є$ висока потреба в породах гусей, добре пристосованих до місцевих умов утримання, 3 високою інтенсивністю відтворення та росту і добрими відгодівельними якостями та якістю продукції. Вивчення специфіки відтворення порід гусей в комплексі
3 ознаками продуктивності дозволить прослідкувати процеси, які призводять до депресії ознак і удосконалити прийоми відтворення генофонду сільськогосподарської птиці (Kovackij and Malyshev, 1991; Sedilo, 2014).

Універсальна продуктивність, невибагливість до умов утримання, здатність споживати об'ємисті корми 3 високим рівнем клітковини - якості, що підтверджують доцільність розведення гусей (Petriv et al., 2016).

Метою даної розробки є збереження оброшинської породної групи гусей з поліпшеними продуктивними якостями. У 2017 році ставилося завдання удосконалити продуктивні якості оброшинських сірих гусей та розширити популяцію при їхньому розведенні «в собі»

\section{Матеріал і методи досліджень}

Дослідження проводилися нами в лабораторії дрібного тваринництва ІСГКР НААН та ДП ДГ «Грусятичі».

Селекційна робота проводиться шляхом індивідуально-масового відбору, спрямована на закріплення стандартних для кожної породної групи ознак. Перед початком племінного періоду самці та самки всіх породних груп були індивідуально оцінені за екстер'єром, типовістю оперення, живою масою. Протягом продуктивного періоду на груповому рівні проводився облік несучості, заплідненості, виводимості яєць, виводу молодняку. В добовому віці проведено жорсткий відбір гусенят за екстер'єром. В процесі вирощування гусенят 3 живою масою, меншою за середнє значення у стаді, у 9- та 26-тижневому віці буде вибраковано. При цьому за зовнішніми ознаками був проведений відбір гусей 3 добре розвинутими м'ясними формами при відсутності у них дефектів екстер'єру, визначалися проміри статей тіла, асоційовані 3 м'ясними формами. В процесі вирощування враховано збереженість молодняку до 9-тижневого віку (Viktorov and Men'kin, 1991). 
У дослідах використовувалася птиця оброшинської породної групи.

3 поголів'я гусей було сформовано дві групи птиці по 50 голів в кожній, які на період парування та яйцекладки (з січня по травень) утримувалися роздільно із забезпеченням належного рівня годівлі та режиму утримання. Облік несучості проводився щоденно 3 вирахуванням індексу форми яєць шляхом лінійного вимірювання та зважування і відбору за цим показником та масою їх для інкубації. Нагромадження інкубаційних яєць та контроль за їх зберіганням проводився кожні 7 днів, після чого вони відправлялися на інкубацію.

Молодняк, починаючи 3 одноденного віку, був помічений і поставлений на роздільне вирощування згідно 3 генотипом. Годівлю до 3-тижневого віку здійснювали спеціально розробленим комбікормом із врахуванням всіх показників нормованої годівлі . До 21-тижневого віку проводився контроль за ростом та розвитком гусенят (подекадне зважування та взяття основних промірів статей тіла).

У 2017 селекційна робота проводилась із застосуванням внутрішньопородного розведення оброшинських сірих гусей «в собі» (табл. 1).

\section{Таблиця 1}

Схема досліду , $(\mathrm{n}=50)$

\begin{tabular}{|c|c|c|}
\hline \multirow[t]{2}{*}{ q } & \multicolumn{2}{|c|}{ породи і породні групи } \\
\hline & $\mathrm{OC}-3 \sigma^{\lambda}$ & $\mathrm{OC}-5 \sigma^{\lambda}$ \\
\hline $\mathrm{OC}-3$ ㅇ & $\mathrm{X}$ & \\
\hline $\mathrm{OC}-5$ 古 & & $\mathrm{X}$ \\
\hline
\end{tabular}

Примітка: ОС - оброшинська сіра

Таблиця 2

Несучість та інкубаційні якості яєць
Селекційно-племінна робота проводилася 3 використанням інструментальних методів та найновіших рекомендацій щодо застосування фізіологобіохімічних маркерів (кров і перо-пухова сировина) 3 контролем екстер'єрних показників, аналізу методом варіаційної статистики.

Поголів'я гусей, не задіяних у дослідженнях в 2017 році, утримувалося окремо і отриманий від них молодняк реалізовувався господарствам та населенню.

\section{Результати та їх обговорення}

Середня жива маса гусей на початок яйцекладки становила (ОС - 39 Х ОС - 3今): гуски - 6,10 кг, гусаки $-7,30$ кг, а $(\mathrm{OC}-5$ ㅇ Х ОС - 5今): гуски - 6,30 кг, гусаки - 7,37 кг.

Несучість - важлива ознака продуктивності, яка залежить від породних та індивідуальних особливостей птиці і умов утримання та годівлі. Середня несучість ОС-3 гусок становила 39,5 штук яєць на голову, а ОС-5 - 41,4 штук яєць. При цьому, середня маса яйця у I групі становила 154,3 г, а у II - 158,5 г. Поряд iз зважуванням щоденно бралися проміри яєць (довжина і ширина) та визначали індекс форми яєць. Ці показники у I групі становили: довжина яйця 84,4 мм, ширина - 55,4 мм., індекс форми 65,6, у II групі відповідно - 84,3 мм; 56,3 мм; 66,7 мм.

У результаті проведених нами досліджень встановлено, що вищими показниками несучості відзначилася друга група (табл. 2).

\begin{tabular}{|c|c|c|}
\hline \multirow{2}{*}{ Показники } & \multicolumn{2}{|c|}{ Група гусей } \\
\hline & 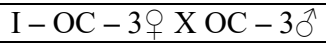 & $\mathrm{II}-\mathrm{OC}-5$ ㅇ X OC $-5 \hat{\jmath}$ \\
\hline Тривалість яйцекладки, днів & 94 & 96 \\
\hline Середня несучість, шт. яєць & 39,5 & 41,4 \\
\hline Середня маса яйця, г & 154,3 & 158,5 \\
\hline Довжина яйця, мм & 84,4 & 84,3 \\
\hline Ширина яйця, мм & 55,4 & 56,3 \\
\hline Індекс форми & 65,6 & 66,7 \\
\hline Міцність шкаралупи, кг/мм² & 2,14 & 2,16 \\
\hline Товщина шкаралупи, мм & 0,49 & 0,55 \\
\hline
\end{tabular}

Отже, з наведених вище даних видно, що показник несучості у гусок II групи був вищим ніж у I групі на $4,8 \%$.

Розвиток гусівництва повинен відбуватися як за рахунок збільшення маточного поголів'я, так і за рахунок підвищення яйценесучості та проценту виведення гусенят.

Вищі показники довжини і ширини яєць були у гусок II групи в період інтенсивної яйцекладки, але значної різниці між групами не виявлено. Індекс форми яєць змінювався по-іншому - на початок яйцекладки він був дещо вищим, ніж в період інтенсивної яйцекладки, тимчасом як в кінці він був найвищим. За цим показником вірогідної різниці не встановлено, так як і за тривалістю яйцекладки, котра становила в середньому 3 місяці.

Вивчення інкубаційних якостей яєць (табл. 3) свідчить, що вища запліднюваність була у гусок II групи i становила 85,3\%, що на $0,9 \%$ більше порівняно 3 І групою. Відомо, що вивід гусенят залежить від запліднюваності і у I групі цей показник становив $71,8 \%$, що на 4,3\% менше, ніж у II групі (76,1\%). Одним із показників життєздатності гусей є збереженість за час вирощування. Вивчення збереженості молодняку проводився шляхом обліку падежу гусей під час вирощування. Так, збереженість молодняку I групи становила 90,7\%, у II групі - 93,6\%. Краща збереженість молодняку спостерігалась у гусей II групи. 
Таблиця 3

Результати інкубації гусячих яєць, \%

\begin{tabular}{ccccc}
\hline Група & Запліднюваність & Задохлики & Вивід гусенят & Збереженість \\
\hline I & 84,5 & 4,5 & 71,8 & 90,7 \\
II & 85,3 & 5,0 & 76,1 & 93,6 \\
\hline
\end{tabular}

Для повнішої характеристики процесів росту і розвитку гусей в різні вікові періоди були проведені виміри статей їх тіла. В своїй роботі ми використовували такі основні проміри статей тіла, як обхват грудей, довжина тулуба, кіля і плюсни. У всі вікові періоди гусенята II групи переважали своїх ровесників за даними показниками. Дані вимірювань наведено в табл. 4.

У 9-тижневому віці самці II групи переважали своїх ровесників з I групи за обхватом грудей на 1,79\%. За довжиною тулубу самці II групи переважали самців I групи на 2,08\%, а за довжиною кіля самці II групи переважали своїх ровесників з I групи на 7,14\%. Така ж тенденція зберігалася і у промірах гомілки та плюсни, так самці II групи за першим показником переважали самців I групи на 8,19\%; за другим показником самці II групи переважали самців I групи на $6,68 \%$.

У 9-тижневому віці самки II групи за обхватом грудей переважали своїх ровесниць 3 I групи на $2,40 \%$, за довжиною тулуба самки II групи переважали самок з I групи на 3,21\%. За довжиною кіля самки II групи переважали своїх ровесниць 3 I групи на 2,34\%. Проміри гомілки та плюсни у самок II групи були найбільші та переважали самок I групи за першим показником на 5,26\%, за другим показником самки II групи переважали самок I групи на 1,08\%.

\section{Таблиця 4}

Проміри основних статей тіла, см $(\mathrm{M} \pm \mathrm{m})$

\begin{tabular}{|c|c|c|c|c|c|c|}
\hline \multirow{2}{*}{ Група } & \multirow{2}{*}{ Стать } & \multirow{2}{*}{ Обхват грудей } & \multicolumn{2}{|c|}{ Довжина } & \multirow{2}{*}{ Гомілка } & \multirow{2}{*}{ Плюсна } \\
\hline & & & тулубу & кіля & & \\
\hline \multicolumn{7}{|c|}{ 1-й день } \\
\hline \multirow{2}{*}{ I } & самці & $11,9 \pm 0,12$ & $11,3 \pm 0,16$ & $2,5 \pm 0,14$ & $5,0 \pm 0,20$ & $3,8 \pm 0,11$ \\
\hline & самки & $10,3 \pm 0,17$ & $10,6 \pm 0,14$ & $2,3 \pm 0,15$ & $4,6 \pm 0,09$ & $3,7 \pm 0,15$ \\
\hline \multirow{2}{*}{ II } & самці & $12,1 \pm 0,46$ & $12,0 \pm 0,20$ & $2,6 \pm 0,10$ & $5,2 \pm 0,12$ & $3,9 \pm 0,20$ \\
\hline & самки & $10,5 \pm 0,42$ & $11,0 \pm 0,10$ & $2,4 \pm 0,20$ & $4,9 \pm 0,13$ & $3,8 \pm 0,13$ \\
\hline \multicolumn{7}{|c|}{4 тижні } \\
\hline \multirow{2}{*}{ I } & самці & $28,3 \pm 0,19$ & $29,6 \pm 0,13$ & $10,2 \pm 0,19$ & $13,8 \pm 0,13$ & $8,8 \pm 0,10$ \\
\hline & самки & $28,0 \pm 0,18$ & $28,0 \pm 0,15$ & $8,3 \pm 0,11$ & $11,8 \pm 0,18$ & $7,6 \pm 0,11$ \\
\hline \multirow{2}{*}{ II } & самці & $28,8 \pm 0,11$ & $29,9 \pm 0,10$ & $10,4 \pm 0,15$ & $14,4 \pm 0,50$ & $9,2 \pm 0,12$ \\
\hline & самки & $28,3 \pm 0,20$ & $28,2 \pm 0,18$ & $9,0 \pm 0,19$ & $13,0 \pm 0,17$ & $8,4 \pm 0,11$ \\
\hline \multicolumn{7}{|c|}{9 тижнів } \\
\hline \multirow{2}{*}{ I } & самці & $39,1 \pm 0,22$ & $33,5 \pm 0,14$ & $12,6 \pm 0,17$ & $18,3 \pm 0,40$ & $10,5 \pm 0,24$ \\
\hline & самки & $37,4 \pm 0,13$ & $31,1 \pm 0,13$ & $12,8 \pm 0,09$ & $17,1 \pm 0,20$ & $9,2 \pm 0,30$ \\
\hline \multirow{2}{*}{ II } & самці & $39,8 \pm 0,21$ & $34,2 \pm 0,08$ & $13,5 \pm 0,11$ & $19,6 \pm 0,15$ & $11,2 \pm 0,15$ \\
\hline & самки & $38,3 \pm 0,19$ & $32,1 \pm 0,10$ & $13,1 \pm 0,10$ & $18,0 \pm 0,18$ & $9,3 \pm 0,19$ \\
\hline \multicolumn{7}{|c|}{12 тижнів } \\
\hline \multirow{2}{*}{ I } & самці & $53,2 \pm 0,11$ & $42,6 \pm 0,20$ & $18,7 \pm 0,12$ & $15,2 \pm 0,10$ & $9,5 \pm 0,08$ \\
\hline & самки & $53,7 \pm 0,12$ & $43,3 \pm 0,25$ & $19,2 \pm 0,14$ & $16,4 \pm 0,21$ & $10,5 \pm 0,17$ \\
\hline \multirow{2}{*}{ II } & самці & $54,3 \pm 0,13$ & $43,0 \pm 0,14$ & $19,2 \pm 0,11$ & $16,1 \pm 0,19$ & $11,2 \pm 0,35$ \\
\hline & самки & $55,1 \pm 0,22$ & $43,9 \pm 0,50$ & $19,6 \pm 0,09$ & $16,8 \pm 0,17$ & $11,5 \pm 0,10$ \\
\hline
\end{tabular}

Також нами вивчались гематологічні показники піддослідних гусей. Проведені дослідження вмісту загального білка в сироватці крові гусей залежно від віку, породи і статі. Дані про вміст загального білка в сироватці крові гусей залежно від віку, породи і статі наведені в табл. 5. Так, самці у всіх досліджуваних періодах мали вищі показники вмісту загального білка в сироватці крові, ніж самки. Найбільш низький цей показник був у самців і самок в чотиритижневому віці. Вміст загального білка в сироватці крові мав незначні коливання. Кров сільськогосподарської птиці має слаболужну реакцію. Кількість крові стосовно до маси тіла гусей становить в середньому 8,5\%. Кількість еритроцитів в організмі гусей непостійна i може змінюватися залежно від рівня годівлі, породи, фізіологічного стану та інших факторів. Дані дослідження кількості еритроцитів і гемоглобіну в крові самок та самців дослідних груп наведені в табл. 5 .

В досліджуваних самок і самців різниця за кількістю еритроцитів незначна. Якщо $з$ віком у молодняку кількість еритроцитів майже не міняється, то вміст гемоглобіну, навпаки, з віком збільшується. Встановлено, що самці у всіх досліджуваних періодах мали вищі показники вмісту загального білка в сироватці крові порівняно з самками.

При вивченні перо-пухової продуктивності молодняку гусей нами було проведено два прижиттєвих скубання - у 11- та 18-тижневому віці й досліджено фракційний склад одержаної сировини (табл. 6). 
Таблиця 5

Гематологічні показники крові гусей $(\mathrm{n}=5)$

\begin{tabular}{|c|c|c|c|c|c|c|c|c|}
\hline \multirow{3}{*}{ Група } & \multicolumn{8}{|c|}{ Вік гусей, тижні } \\
\hline & \multicolumn{2}{|c|}{1 день } & \multicolumn{2}{|c|}{4 тижні } & \multicolumn{2}{|c|}{9 тижнів } & \multicolumn{2}{|c|}{12 тижнів } \\
\hline & самці & самки & самці & самки & самці & самки & самці & самки \\
\hline \multicolumn{9}{|c|}{ Гемоглобін, г\% } \\
\hline I & $14,0 \pm 0,20$ & $13,9 \pm 0,20$ & $16,0 \pm 0,12$ & $15,9 \pm 10,0$ & $16,2 \pm 0,11$ & $16,0 \pm 0,14$ & $16,4 \pm 0,14$ & $16,2 \pm 0,15$ \\
\hline II & $14,2 \pm 10,0$ & $13,7 \pm 0,14$ & $16,9 \pm 0,13$ & $15,7 \pm 0,19$ & $16,4 \pm 0,11$ & $15,9 \pm 0,11$ & $16,5 \pm 0,13$ & $16,2 \pm 0,10$ \\
\hline \multicolumn{9}{|c|}{ Еритроцити, млн $/ 1 \mathrm{~cm}^{3}$} \\
\hline I & $3,45 \pm 0,006$ & $3,40 \pm 0,019$ & $4,00 \pm 0,011$ & $4,10 \pm 0,025$ & $4,44 \pm 0,016$ & $4,44 \pm 0,015$ & $4,49 \pm 0,014$ & $4,48 \pm 0,025$ \\
\hline II & $3,52 \pm 0,009$ & $3,42 \pm 0,010$ & $4,18 \pm 0,018$ & $4,10 \pm 0,009$ & $4,50 \pm 0,018$ & $4,44 \pm 0,008$ & $4,52 \pm 0,013$ & $4,48 \pm 0,010$ \\
\hline \multicolumn{9}{|c|}{ Загальний білок, г \% } \\
\hline I & $5,09 \pm 0,19$ & $4,36 \pm 0,06$ & $4,66 \pm 0,11$ & $3,96 \pm 0,16$ & $5,62 \pm 0,10$ & $5,62 \pm 0,10$ & $5,43 \pm 0,10$ & $5,36 \pm 0,10$ \\
\hline II & $5,13 \pm 0,11$ & $4,89 \pm 0,05$ & $4,73 \pm 0,12$ & $3,84 \pm 0,03$ & $5,81 \pm 0,13$ & $5,47 \pm 0,13$ & $5,62 \pm 0,16$ & $5,28 \pm 0,09$ \\
\hline
\end{tabular}

Таблиця 6

Фракційний склад перо-пухової сировини, одержаної шляхом прижиттєвого скубання гусей, \%

\begin{tabular}{|c|c|c|c|c|c|}
\hline \multirow{2}{*}{ Групи гусей } & \multicolumn{2}{|c|}{ Перо } & \multicolumn{2}{|c|}{ Пух } & \multirow{2}{*}{$\begin{array}{c}\text { Засміченість, } \\
\% \\
\end{array}$} \\
\hline & Зріле & Незріле & Зріле & Незріле & \\
\hline \multicolumn{6}{|c|}{11 тижнів } \\
\hline I & 68,6 & 7,1 & 15,1 & 5,1 & 5,6 \\
\hline II & 67,2 & 8,7 & 14,1 & 5,6 & 6,9 \\
\hline \multicolumn{6}{|c|}{18 тижнів } \\
\hline I & 61,0 & 3,2 & 34,2 & 2,3 & 1,8 \\
\hline II & 59,6 & 3,7 & 33,4 & 2,8 & 3,0 \\
\hline
\end{tabular}

У сировині, одержаній при першому скубанні від гусей I групи, був дещо вищий відсоток пера і пуху, а незрілого - менший. При другому скубанні порівняно 3 першим зросла кількість пуху майже в три рази. Знизився вміст незрілого і засміченого пера i пуху. Статистично вірогідної різниці між групами за вмістом перо-пухової сировини нами не виявлено, але гуси I групи проявляють тенденцію до поліпшення перо-пухових якостей.

Отже, проведеними дослідженнями встановлено, що гуси були добре відселекціоновані за продуктивними ознаками і показали високі репродуктивні якості зі збереженням бажаного екстер'єру та відсутністю негативних змін показників крові. Вся птиця добре пристосована до природніх умов західного регіону.

\section{Висновки}

В умовах західного регіону сірі гуси оброшинської селекції добре пристосовані до місцевих умов годівлі та утримання. Науково-дослідна робота була спрямована на збереження, удосконалення та розширення популяції. На основі проведених досліджень зроблено такі висновки:

1. Показники продуктивності оброшинських сірих гусей (I група) становили: несучість - 39,5 шт. на голову; маса яйця - 154,3 г; запліднюваність - 84,4\%; виводимість - 71,8\%; жива маса гусей в 9-тижневому віці: самці - 4,52 кг, самки - 3,84 кг; збереженість $90,7 \%$.

2. Оброшинські сірі гуси (II група) характеризуються стосовно до I групи відповідно вищими показниками: за несучістю на $4,8 \%$, запліднюваністю 0,9\%, виводимістю - 4,9\%, живою масою гусей в 9- тижневому віці (самці) - 1,99\%, (самки) на 0,52\%, збережненістю - 2,90\%, масою яйця - 2,64\%.

3. Вищу перо-пухову сировину було одержано у 18-тижневому віці в гусей І групи.

4. Основні показники крові піддослідних гусей перебували в допустимих межах норми.

Перспективи подальших досліджень. Надалі ми плануємо проводити дослідження із наявним поголів'ям гусей для ще кращої консолідації бажаних ознак продуктивності та відтворювальної здатності гусей та значного збільшення поголів'я цих птахів в господарствах усіх форм власності в західному регіоHi.

\section{References}

Hunchak, A., Hunchak, V.M., \& Ratych, I.B. (2015). Biological effects of plants extracts in the poultry. Scientific Messenger of LNU of Veterinary Medicine and Biotechnologies. 17(3), 19-31. Retrieved from: https://nvlvet.com.ua/index.php/ journal/article/view/513.

Kovackij, N.S., \& Malyshev, V.V. (1991). Razvodite gusej. M.: Agropromizdat (in Russian).

Medvid, S., Hunchak, A., Gutyj, B., \& Ratych, I. (2017). Prospects of rational security chicken-broilers with mineral substances. Scientific Messenger of LNU of Veterinary Medicine and Biotechnologies. 19(79), 127-134. doi: 10.15421/nvlvet7925.

Petriv, M., Sloboda, L., \& Sloboda, O. (2017). Intensity of growth and development of the young of obroshyno gray geese generation crossed with big gray breed geese, $f$ ii generation, crossed with geese big seed of breed. Scientific Messenger of LNU of Veterinary Medicine and Biotechnologies. 19(74), 219-223. 
Retrieved from: https://nvlvet.com.ua/index.php/ journal/article/view/1136.

Petriv, M., Sloboda, L., \& Sloboda. O. (2016). meat and feather and down performance obroshynskyh gray geese ii generation, crossed with a big gray breed. Scientific Messenger of LNU of Veterinary Medicine and Biotechnologies. 18(2(67), 178-182. doi: $10.15421 /$ nvlvet6740.

Petriv, M., Sloboda, L., Zahorets, N., \& Sloboda, O. (2015). Exterior features and quality of feathers obroshynskyh gray and white geese in breeding. Scientific Messenger of LNU of Veterinary Medicine and Biotechnologies. 17(3), 281-286. Retrieved from: https://nvlvet.com.ua/index.php/ journal/article/view/562.

Petriv, M.D., Sloboda, L.Ia., Zahorets, N.M., \& Sloboda, O.M. (2016). Pleminni ta produktyvni yakosti obroshynskykh sirykh i bilykh husei pry yikh rozvedenni. Visnyk ahrarnoi nauky, 41-44. Rezhym dostupu: http://agrovisnyk.com/pdf/ua_2016_01_08.pdf
Rojter, Ja.S., Davtjan, A.D., \& Egorova, A.V. (2007). Instrukcii po kompleksnoj ocenke plemennyh kachestv sel'skohozjajstvennoj pticy (jaichnye i mjasnye kury, gusi, utki, indejki, cesarki) Sergiev Posad: VNITIP (in Russian).

Sedilo, H.M. (2014). Zabiini pokaznyky obroshynskykh husei pry yikh rozvedenni «v sobi». Peredhirne ta hirske zemlerobstvo ta tvarynnytstvo. 56(II), 35-28 (in Ukrainian).

Sedilo, H.M., Sloboda, L.Ya., Petriv, M.D., Zahorets, N.M., Tesak, H.V., \& Khomyk, M.M. (2014). Reproduktyvni ta pero-pukhovi yakosti obroshynskykh husei pry rozvedenni «V sobi». Peredhirne ta hirske zemlerobstvo i tvarynnytstvo. 56(2), 198-204 (in Ukrainian).

Viktorov, P.I., \& Men'kin, V.K. (1991). Metodika i organizacija zootehnicheskih opytov. M.: Agropromizdat (in Russian). 